\title{
Clinical characteristic of Diabetic Nephropathy in Patients with Type 2 Diabetic Mellitus Obtaining hemodialysis: A Retrospective Analysis of 63 Cases
}

\author{
Yulduz Makhkamovna Urmanova ${ }^{1 *}$ and Alisher Yusupovich Kholikov ${ }^{2}$ \\ ${ }^{1}$ Doctor of Medical Sciences, Associate Professor of the Department of Endocrinology with Pediatric Endocrinology of the \\ Tashkent Pediatric Medical Institute, Uzbekistan
}

${ }^{2}$ Head of the Department of Hemodialysis, Republican Specialized Scientific and Practical Medical Center for Endocrinology named by Academy, Uzbekistan

*Corresponding author: Yulduz Makhkamovna Urmanova, Doctor of Medical Sciences, Associate Professor of the Department of

Endocrinology with Pediatric Endocrinology of the Tashkent Pediatric Medical Institute, Uzbekistan

\begin{tabular}{|c|c|}
\hline ARTICLE INFO & ABSTRACT \\
\hline Received: 崫 July 01, 2020 & Citation: Yulduz Makhkamovna U, Alisher Yusupovich K. Clinical characteristic of \\
\hline Published: & $\begin{array}{l}\text { Diabetic Nephropathy in Patients with Type } 2 \text { Diabetic Mellitus Obtaining hemodialysis: } \\
\text { A Retrospective Analysis of } 63 \text { Cases. Biomed J Sci \& Tech Res 28(5)-2020. BJSTR. } \\
\text { MS.ID.004706. }\end{array}$ \\
\hline
\end{tabular}

\section{Introduction}

Diabetes prevalence is increasing worldwide, with the highest increases in low- and middle-income countries. In most developed countries, type 2 diabetes is currently the main cause of end-stage renal failure and also contributes significantly to cardiovascular disease. In countries with weaker economies, type 2 diabetes is rapidly replacing infectious diseases as a leading cause of kidney disease and is increasingly competing for scarce health resources. The frequency of chronic renal failure varies in different countries in the range of 100-600 per 1 million adults. Moreover, 50-100 new cases of uremia are registered annually. There is a different frequency of chronic renal failure in different age groups: from 4-10 cases per 1 million in children to $1-3$ cases per 10,000 in adults, especially in people over 70 years of age. This is due to the fact that with age, the structure of the causes of chronic renal failure significantly changes, new etiological factors appear. While in children mainly chronic hereditary and congenital nephropathies lead to chronic renal failure: Alport syndrome, cystinosis, reflux nephropathy, in adults - acquired primary and secondary nephropathies.

In older people, the cause of chronic renal failure can be metabolic and vascular diseases (diabetes mellitus, gout, hypertension, atherosclerosis), urological and oncological diseases, the use of drugs, especially polypharmacy, etc. [1]. In order to unify

approaches to the diagnosis, treatment and prevention of renal pathology in 2002, associations of nephrologists and hemodialysis doctors from Europe and the USA - NKF / KDOQI (National Kidney Foundation / Kidney Disease Outcomes Quality Initiative) proposed a new term: Chronic kidney disease chronic kidney disease). CKD is defined as damage to the kidneys or a decrease in their function within three months or more, regardless of diagnosis [2]. Changes in the nervous system in patients with CKD stage $\mathrm{V}$ largely determine their fate, being the cause of persistent disability and death [3]. Until now, the unsolved problem is the search for adequate treatment for patients with end-stage chronic renal failure, with various neurological complications, developing with the use of hemodialysis [4,5]. According to various authors, the frequency of neurological manifestations in patients receiving hemodialysis is from 40 to $90 \%$ [6,7], Mortality from neurological complications is $7-25 \%$, and among patients with advanced cerebrovascular accident: 80-90\% [8].

John T. Dandirdas [9] proposed a classification of Central Nervous System (CNS) disorders in hemodialysis patients:

a) Acute cerebrovascular accident during hemodialysis or immediately after it 
b) Chronic dementia on regular programmed hemodialysis

c) Subclinical manifestations of brain disorders in adequately treated patients

d) Acute disorders of brain functions that are not associated with dialysis but are the result of uremia or that have occurred in previously stable patients.

A high likelihood of developing CNS disorders in patients with kidney damage is primarily associated with the formation of systemic endothelial dysfunction and remodeling of cerebral vessels, which prevents adequate regulation of cerebral blood flow. Violation of cerebral perfusion is the root cause of the development of encephalopathy, transient cerebrovascular accident, stroke [10]. Discirculatory Encephalopathy (DE) is one of the most common complications of chronic renal failure in patients with programmed hemodialysis. The most important pathogenetic mechanism for the development of DE is arterial hypertension (AH), which, according to various authors, occurs in $80-100 \%$ of patients [11] and is a risk factor for morbidity and mortality from cardiovascular and cerebrovascular diseases $[12,13]$. The higher the systolic blood pressure and the longer arterial hypertension exists, the greater the degree of atrophy of the brain. G.M. Savazzi studied the degree of brain atrophy in patients with verified arterial hypertension who received treatment with programmed hemodialysis using computed tomography. Patients under the age of 55 were included in the study group to exclude the effect of age-related changes [14-18]. When conducting computed tomography in all patients, cerebral atrophy of varying severity was revealed. All of the above was the reason for the present study.

\section{Aim of the Study}

To study the clinical characteristic of the patients with type 2 diabetes mellitus.

\section{Material and Methods}

We examined and examined in total for the period from January 1, 2019 to December 31, 2019 - 63 patients suffering from type 2 diabetes mellitus, with chronic renal failure III stage. on programmed hemodialysis. Of these, 32 were women and 31 were men. The average age of men was $67 \pm 4.2$ years, and the average age of women was $64 \pm 5.6$ years. 20 patients of the corresponding age made up the control group. The number of hemodialysis sessions in patients ranged from $2 \mathrm{x}$ to 162 .

\section{Inclusion Criteria}

Patients with type 2 diabetes mellitus who are on program hemodialysis, with chronic renal failure III st., Diabetic nephropathy $5^{\text {th }}$.

\section{Exclusion Criteria}

pregnant women, children and young people with type 1 diabetes, patients with pathology of the cardiovascular system before the diagnosis of type 2 diabetes, autoimmune thyroiditis (hypothyroidism). According to the degree of chronic cerebral ischemia (CCI), patients were divided into 3 groups: 1 g. - 27 (42.9\%) patients with stage 5 diabetic nephropathy with grade 1 of CCI; 2 gr. - 23 (36.5\%) patients with stage 5 diabetic nephropathy with grade 2 of CCI; 3 gr - 13 (20.6\%) patients with stage 5 diabetic nephropathy with grade 3 of CCI. All 63 patients underwent all studies, including general clinical (general blood count, general urine analysis according to Nechiporenko), biochemical (blood sugar, glycemic profile, glycated hemoglobin HbA1C, urea, creatinine, blood electrolytes, lipid spectrum, coagulogram, etc.), hormonal blood tests (C-peptide, insulin) of the laboratory of radioimmune hormonal studies of the RSNPMC Endocrinology of the Ministry of Health of the Republic of Uzbekistan (head laboratory assistant doctor of biological sciences Abdurakhmanova AM RIA studies of blood serum were carried out on counters "Gamma-12" and "Strantg 300 "), ECG, ultrasound of internal organs, dopplerography of the main arteries of the head, if necessary, patients were referred for follow-up examinations, radiological, ultrasound of internal and genital organs, consultation with a cardiologist, neurologist, nephrologist, ophthalmologist, surgeon, and other studies. We assessed the quality of life of patients before hemodialysis and in the dynamics of treatment using the WHO Brief Questionnaire on Quality of Life Assessment (WHOQOL-BREF) and the Hamilton Depression Scale. The data obtained were processed using computer programs Microsoft Excel and STATISTICA_6. The mean values $(\mathrm{M})$, standard deviations of the means (m) were calculated. The significance of differences in the level between the groups was estimated by the value of the confidence interval and Student's criterion (p). Differences were considered statistically significant at $\mathrm{p}<0.05[19,20]$.

\section{Results and Discussion}

Table 1 shows the distribution of the examined patients by gender and age. As can be seen from Table 1, patients in the age category from 60 to 74 years prevailed among both men and women - 18/20 cases, respectively. As can be seen from Table 2, the predominant number of patients received hemodialysis for up to 1 year - $26(41.3 \%)$ patients, and the smallest number - up to 5 and 6 years ( $2 / 2$ patients, respectively). Besides that, the prevalence of DN is high in patients with DM 2 type manifesting heavy proteinuria. Patients presented various complaints during the examination, indicating the presence of CCI. The most common complaints were fatigue - 63 (100\%), headaches - 58 patients (92.4\%), dizziness $43(68.3 \%)$, noise in the head - 41 (65.0\%), decrease memory - 39 $(61.8 \%)$, violation of the sleep formula - 33 (52.4\%)\%, heart pain - 27 (42.8)\%, that is, these complaints are most characteristic of chronic vascular cerebral insufficiency and were dominant. Table 3 shows the frequency of concomitant diseases identified in patients in groups. As follows from Table 3, in total among 63 patients 32 $(50.8 \%)$ patients with iodine deficiency diseases of the thyroid 
gland were identified: diffuse goiter (DG) 1 st - 23 patients (36.5\%), syndrome - in 33 (52.4\%), chronic hepatitis - in 24 (38.0\%), chronic diffuse goiter 2 st - 9 patients (14.3\%), arterial hypertension (AH) pancreatitis - in 14 (22.2\%), chronic cholecystitis - 20 (31.7\%).

Table 1: Distribution of patients by gender and age (WHO, 2017).

\begin{tabular}{|c|c|c|}
\hline Age, years & Number of men & Number of women \\
\hline $18-44$ (young age) & $3(9,7 \%)$ & $6(18,7 \%)$ \\
\hline $45-59$ (middle-aged) & $8(25,8 \%)$ & $6(18,7 \%)$ \\
\hline $60-74$ (elderly age) & $18(58,0 \%)$ & $20(62,5 \%)$ \\
\hline 75 and older (senile age) & $2(6,4 \%)$ & - \\
\hline Total $: \mathrm{n}=63$ & $31(49,2 \%)$ & $32(50,8 \%)$ \\
\hline
\end{tabular}

Table 2: The duration of the resulting program analysis in groups. (abs. numbers and \%).

\begin{tabular}{|c|c|c|c|c|c|c|c|}
\hline \multirow[b]{2}{*}{ № } & \multirow{2}{*}{$\begin{array}{c}\text { Duration of hemodialysis, } \\
\text { years }\end{array}$} & \multicolumn{3}{|c|}{ The group } & \multicolumn{3}{|c|}{$\%$ of the total number in the group } \\
\hline & & $\begin{array}{c}1 \mathrm{gr} \\
\mathrm{n}=27\end{array}$ & $\begin{array}{c}2 \mathrm{gr} \\
\mathrm{n}=23\end{array}$ & $\begin{array}{c}3 \mathrm{gr} \\
\mathrm{n}=13\end{array}$ & $\begin{array}{c}1 \text { gr } \\
\mathrm{n}=27\end{array}$ & $\begin{array}{c}2 \text { gr } \\
n=23\end{array}$ & $\begin{array}{c}3 \text { gr } \\
n=13\end{array}$ \\
\hline 1 & Up to 1 year, $\mathrm{n}=26$ & 9 & 10 & 7 & 33,3 & 43,4 & 53,8 \\
\hline 2 & $\begin{array}{c}\text { From } 1 \text { year to } 2 \text { years, } \mathrm{n} \\
=12\end{array}$ & 4 & 5 & 3 & 14,8 & 21,7 & 23,0 \\
\hline 3 & 2 years, $\mathrm{n}=8$ & 2 & 4 & 2 & 7,4 & 17,4 & 15,3 \\
\hline 4 & 3 years, $\mathrm{n}=7$ & 2 & 3 & 1 & 7,4 & 13,0 & 7,7 \\
\hline 5 & 4 years, $n=5$ & 3 & 1 & 1 & 18,5 & 4,3 & 7,7 \\
\hline 6 & 5 years, $\mathrm{n}=2$ & 2 & - & - & 7,4 & - & - \\
\hline 7 & 6 years, $\mathrm{n}=2$ & 2 & - & - & 7,4 & - & - \\
\hline 8 & 7 years, $n=3$ & 3 & - & - & 11,1 & - & - \\
\hline & Total & $\mathrm{n}=27$ & $\mathrm{n}=23$ & $\mathrm{n}=3$ & & & \\
\hline
\end{tabular}

Table 3: The frequency of concomitant diseases in groups (abs. numbers and \%).

\begin{tabular}{|c|c|c|c|c|c|c|c|}
\hline \multirow[b]{2}{*}{ № } & \multirow[b]{2}{*}{ Disease } & \multicolumn{3}{|c|}{ Group } & \multicolumn{3}{|c|}{$\%$ of the total number in the group } \\
\hline & & $\begin{array}{c}1 \text { gr } \\
n=27\end{array}$ & $\begin{array}{c}2 \mathrm{gr} \\
\mathrm{n}=23\end{array}$ & $\begin{array}{c}3 \mathrm{gr} \\
\mathrm{n}=13\end{array}$ & $\begin{array}{c}1 \text { gr } \\
n=27\end{array}$ & $\begin{array}{c}2 \text { gr } \\
\mathrm{n}=23\end{array}$ & $\begin{array}{r}3 \mathrm{gr} \\
\mathrm{n}=13\end{array}$ \\
\hline 1 & $\begin{array}{l}\text { Diffuse goiter } 1 \text { st. } \\
\text { Euthyroidism }\end{array}$ & 11 & 7 & 5 & 40,7 & 30,4 & 38,5 \\
\hline 2 & $\begin{array}{l}\text { Diffuse goiter } 2 \text { st. } \\
\text { Euthyroidism }\end{array}$ & 3 & 4 & 2 & 11,1 & 17,4 & 15,4 \\
\hline 3 & $\begin{array}{l}\text { Arterial Hypertension } \\
\text { syndrome }\end{array}$ & 17 & 8 & 8 & 62,9 & 34,8 & 61,5 \\
\hline 4 & Chronic hepatitis & 13 & 4 & 7 & 48,1 & 17,4 & 53,8 \\
\hline 5 & Chronic pancreatitis & 5 & 3 & 6 & 18,5 & 13,0 & 46,1 \\
\hline 6 & Chronic cholecystitis & 7 & 8 & 5 & 25,9 & 34,8 & 38,5 \\
\hline
\end{tabular}

Table 4: Risk factors for DN in patients with DM 2 type (according to anamnestic data).

\begin{tabular}{|c|c|c|c|}
\hline $\begin{array}{l}\text { Causes or factors of occurrence } \\
\text { of DN }\end{array}$ & $\begin{array}{c}1 \mathrm{gr} \\
(\mathrm{n}=27) \\
\text { abs (\%) }\end{array}$ & $\begin{array}{c}2 \mathrm{gr} \\
(\mathrm{n}=23) \\
\text { abs (\%) }\end{array}$ & $\begin{array}{c}3 \mathrm{gr} \\
(\mathrm{n}=13) \\
\text { abs }(\%)\end{array}$ \\
\hline Age $>60$ years & $27(100 \%)^{* *}$ & $23(100 \%)^{* *}$ & $13(100 \%)^{* *}$ \\
\hline Duration of diabetes $>15 \mathrm{y}$. & $14(51,9 \%)^{*}$ & $13(56,5 \%)^{*}$ & $8(61,6 \%)^{*}$ \\
\hline Presence of retinopathy & $22(81,4 \%)^{*}$ & $20(86,9 \%)^{*}$ & $12(92,3 \%)^{*}$ \\
\hline 24-h proteinuria & $27(100 \%)^{* *}$ & $23(100 \%)^{* *}$ & $13(100 \%)^{* *}$ \\
\hline Serum albumin higher & $18(66,6 \%)^{*}$ & $16(69,5 \%)^{*}$ & $10(76,9 \%)^{*}$ \\
\hline Smoking & $4(14,9 \%)$ & $6(26,0 \%)$ & $3(23,0 \%)$ \\
\hline SAP increase & $22(81,4 \%)$ & $23(100 \%)$ & $13(100 \%)$ \\
\hline Hepatitis & $13(48,1 \%)$ & $4(17,4 \%)$ & $7(53,8 \%)$ \\
\hline
\end{tabular}




\begin{tabular}{|c|c|c|c|}
\hline Infectious diseases & - & - & - \\
\hline Stress & $27(100 \%)^{* *}$ & $23(100 \%)^{* *}$ & $13(100 \%)^{* *}$ \\
\hline With nothing & - & - & - \\
\hline
\end{tabular}

Note: SAP - systolic arterial pressure, * - significance of differences with control, where * $-p<0.05,{ }^{* *}-p<0.01$.

As can be seen from Table 4, we found a reliable association between the risk of heart failure and age, the duration of diabetes for more than 15 years, the presence of retinopathy, 24-hour proteinuria, serum albumin and SAP. So, the examined among 63 patients, we revealed various disorders of endocrine, neurological status, confirming the presence of cerebrovascular complications in this category of patients. Thus, summarizing the above analysis of the studies performed, it can be noted that such studies should be performed as monitoring for patients with type 2 diabetes mellitus in order to assess their quality of life and early diagnosis of various complications.

\section{Conclusion}

a) Multivariate analysis showed the significant risk factors for DN alone were age, duration of diabetes, presence of retinopathy, 24-h proteinuria, serum albumin and SAP.

b) The prevalence of DN is high in patients with DM 2 type manifesting heavy proteinuria.

\section{References}

1. Brouns R, PP De Deyn (2004) Neurological complications in renal failure: a review. Clinical Neurology and Neurosurgery 107(1): 1-16.

2. Donato R, Riuzzi F, Sorci G (2013) Causes of elevated serum levels of S100 $\beta$ protein in athletes. European Journal of Applied Phisiology 113(3): 819-820.

3. Elif DB, Mustaf A, Serdar K (2013) Comparison of the effect off desflurane and propofol anesthesia on the inflammatory response and S100 $\beta$ protein during coronary artery bypass grafting. Inflamatory 36(6): 1327-1333.

4. John T, Dandirdas, Kunig P, Neyer U (2002) Neurological disease of Renal Failure. Neurology and general medicine. In John T, Dandirdas, Kunig P, Neyer U (Eds.), (3rd edn.). Pp. 131-142.

5. Luca Zazzeroni, Gianandea Pasquinelli, Eleonora Nanni, Valeria Cremonini, Ivan Rubbi (2007) Comparison of Quality of Life in Patients Undergoing Hemodialysis and Peritoneal Dialysis: A Systematic Review and Meta-Analysis Review. Kidney Blood Press Res 42(4): 717-727.

6. Ozer E, Yilmaz R (2017) Effect different anesthetic techniques on mental outcome in elderly patients undergoing off-pump coronary artery bypass graft surgery. J cardiovasc Science 29(1): 17-22.
7. Raskin Neil H (2001) Neurological Aspects of Renal Failure. Neurology and general medicine. In MJ Aminoff (Eds.), (3rd edn.) Pp. 231-246.

8. Yokobori S, Hosein K, Burks S, Sharma I, Gajavelli S (2013) Biomarkers for the clinical differential diagnosis in traumatic brain injury - a systematic review. CNS Neuroscience \& Therapeutics 19(8): 556-565.

9. Yin Bun Cheung, Khung Keong Yeo, Kok Joon Chong, Eric Yin Hao Khoo, Hwee Lin Wee (2019) Measurement Equivalence of the English, Chinese and Malay Versions of the World Health Organization Quality of Life (WHOQOL-BREF) Questionnaires. Health Qual Life Outcomes 17(1): 67.

10. Wenqian Z, Jiapeng L, Yifei S, Jiange H (2016) Changes in postoperative cognitive function during off-pump coronary artery bypass graft surgery: dose response of propofol. Int J Clin Exp Med 9(6): 10939-10946.

11. Wen J Liu, Ramli Musa, Thian F Chew, Christopher T S Lim, Zaki Morad (2014) Quality of Life in Dialysis: A Malaysian Perspective. Hemodial Int 18(2): 495-506.

12. Васильева ИА (2005) Качество жизни больных на хроническом гемодиализе / И. А. Васильева. Нефрология 9(3): 48-54.

13. Васильева ИА (2008) Психологическая адаптация к болезни у лиц с хронической почечной недостаточностью. Обозрения психиатрии и медицинской психологии 2: 27-30.

14. Ваулин ИН (2015) Клинико-патогенетические особенности коррекции изменений нервной системы больных с хронической болезнью почек $\mathrm{V}$ стадии//диссертация на соискание ученой степени кандидата медицинских наук по специальности 14.01.14, Россия, г.Москва Рр. 129.

15. Гендлин ГЕ (2005) Исследование качества жизни пациентов, получающих заместительную почечную терапию гемодиализом и после АТП с помощью универсального опросника SF-36. Нефрология и диализ 7(3): 284.

16. Ермоленко ВМ (2000) Хроническая почечная недостаточность. Нефрология: Руководство для врачей / под редакцией ИЕ Тареевой. 2-е изд, перераб. и доп. - М Рр. 596 - 657.

17. Кудрякова АС (2013) Дисс... канд.мед.наук. Коррекция эндотелиальной дисфункции у больных с хронической болезнью почек. Москва.

18. Парфенов ВА, Вахнина НВ (2001) Артериальная гипертония и гипотензивная терапия при ишемическом инсульте. Неврологический журнал 4: 19-22.

19. Сигитова ОН (2008) Хроническая болезнь почек и хроническая почечная недостаточность: современные подходы к терминологии, классификации и диагностике. Вестн. соврем, клин, медицины 1: 87.

20. Ткалич ЛМ (2003) Качество жизни и функциональное состояние вегетативной нервной системы у больных с хронической почечной недостаточностью : автореф. дис. … канд. мед. наук. - Томск, pp. 25. 
ISSN: 2574-1241

DOI: $10.26717 /$ BJSTR.2020.28.004706

Yulduz Makhkamovna Urmanova. Biomed J Sci \& Tech Res

(C) $(9)$ This work is licensed under Creative

Submission Link: https://biomedres.us/submit-manuscript.php

$\begin{array}{ll}\text { BIOMEDICAL } & \text { Assets of Publishing with us } \\ \text { RESEARCHES } & \text { - Global archiving of articles } \\ \text { - Immediate, unrestricted online access }\end{array}$

